\title{
Animasi Interaktif Pembelajaran Huruf dan Angka Menggunakan Model ADDIE
}

\author{
Interactive Animation of Learning Letters and Numbers using ADDIE Model
}

\author{
Diterima: \\ 30 Januari 2019 \\ Revisi: \\ 17 Februari 2019 \\ Terbit Online: \\ 2 Mei 2019
}

\author{
Syamsul Bakhri \\ Fakultas Teknologi Informasi, Program Studi Teknologi Komputer \\ Universitas Bina Sarana Informatika Jakarta \\ Jakarta, Indonesia \\ E-mail:syamsul.slb@bsi.ac.id
}

\begin{abstract}
Abstrak-Penggunaan teknologi dalam media pembelajaran sangat diperlukan di seluruh institusi pendidikan. Membuat suasana belajar yang menyenangkan melalui sarana multimedia berupa animasi interaktif. Dirasa efektif untuk meningkatkan minat belajar anak-anak dalam mengenal huruf dan angka pada TK RA Nurul Iman Jakarta. Menggunakan jenis research and development dengan model ADDIE. Perhitungan kelayakan aplikasi untuk menghasilkan animasi yang interaktif yang sesuai dengan kebutuhan. Tujuan dari pembuatan media pembelajaran ini membantu siswa untuk dapat lebih mudah memahami dan mengerti serta tidak merasa bosan dalam pembelajaran mulai dari gambar huruf dan angka dan cara pengucapannya. Setelah proses pembelajaran siswa akan mengerjakan kuis dan juga terdapat game agar membuat kecepatan berfikir anak lebih baik. Selain itu aplikasi ini dapat membantu guru dalam proses belajar mengajar yang dianggap sangat membosankan, dengan nilai rata-ratanya 82,6\% menunjukan aplikasi animasi interaktif ini sangat menyenangkan untuk media belajar pengenalan angka dan huruf.
\end{abstract}

Kata Kunci- Animasi Interaktif, ADDIE, Belajar Huruf dan Angka

\begin{abstract}
The use of technology in learning media is very necessary for all educational institutions. Creating a pleasant learning atmosphere through multimedia means in the form of interactive animations. It was felt effective to increase children's learning interest in recognizing letters and numbers at TK RA Nurul Iman Jakarta. Use the type of research and development with the ADDIE model. Calculation of the app's feasibility to produce interactive animations that fit your needs. The purpose of making this learning media helps students to be able to more easily understand and understand and not feel bored in learning to start from letters and numbers and how to pronounce them. After the learning process, students will work on the quiz and there will also be games to make the child's thinking speed better. In addition, this application can help teachers in the teaching and learning process that is considered very boring, with an average value of $82.6 \%$ showing this interactive animation application is very fun for the media to learn the introduction of numbers and letters.
\end{abstract}

Keywords - Interactive Animation, ADDIE, Learning Letters and Numbers

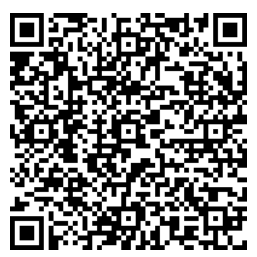




\section{PENDAHULUAN}

Belajar merupakan kegiatan yang tidak akan pernah berhenti dari detik demi detik sejak manusia lahir sampai mati. Manusisa sejak lahir belajar untuk mengenal dirinya juga lingkungannya. oleh karena itu pendidikan anak-anak semakin penting, mengingat perkembangan anak pada masa itu berada pada masa aktif.

Pendidikan harus sudah mulai diberikan kepada anak-anak sejak dini, baik secara formal maupun informal. pendidikan informal diberikan orang tua bagaimana anak bisa mengenal katakata.sedangkan pendidikan formal,di dapat di sekolah bagaimana anak mengenal huruf dan angka. Dengan pendidikan yang benar anak-anak mudah berinteraksi dengan lingkungan. Perkembangan teknologi sekarang ini sangat pesat, baik teknologi informasi maupun teknologi komunikasi. Dalam proses pembelajaran terkadang anak bosan mendengarkan materi yang diberikan tak bervariasi dan tidak adanya sarana atau alat praktek atau media yang dimiliki sekolah. Selama ini pembelajaran di TK RA Nurul iman masih menggunakan buku dan papan tulis yang kurang menarik.

Dalam dunia pendidikan suatu metode pembelajaran dapat dihadirkan dengan menggunakan alat peraga pembelajaran atau sering dikenal media pembelajaran[1]. Komputer dapat dimanfaatkan sebagai media untuk menyampaikan materi pelajaran kepada siswa sebagai media alternatif, salah satu pendidikan yang harus diberikan kepada siswa seperti Aplikasi pembelajaran interaktif huruf dan angka. Tujuan dari penelitian ini adalah menghasilkan aplikasi dan mengetahui persepsi siswa terhadap aplikasi animasi interaktif pembelajaran huruf dan angka pada anak taman kanak-kanak, dengan menggunakan metode ADDIE.

Beberapa penelitian terkait penelitian ini diantaranya yaitu penelitian yang dilakukan oleh Jamilah Karaman, Arief Setyanto dan Amir Fatah Sofyan yang membahas mengenai analisa pembelajaran huruf dimana aplikasi belajar yang dikembangkan yaitu aplikasi marbel adalah aplikasi pendidikan (mobile learning) untuk anak usia 2 hingga 8 tahun sehingga aplikasi berbasis mobile yang dibuat bertujuan untuk memudahkan anak dalam proses belajar [2]. Penelitian yang dilakukan oleh Sidhiq Andriyanto , M. Suyanto, dan Sukoco yang membahas desain 3D. Analisa penelitian tersebut menjadi landasan desain aplikasi pembelajaran yang akan dibuat [3].

\section{METODE PENELITIAN}

Tinjauan pustaka penelitian sebelumnya, Mengenalkan anak-anak kepada jenis hewan dan alat transportasi yang ada disekitar mereka bisa dikatakan penting karena merupakan usaha dini untuk membantu anak-anak ditingkat taman kanak-kanak dalam mengenalkan jenis hewan dan 
INTENSIF, Vol.3 No.2 August 2019

ISSN: 2580-409X (Print) / 2549-6824 (Online)

DOI: https://doi.org/10.29407/intensif.v3i2.12666

alat transportasi. perangkat lunak yang digunakan untuk membuat animasi media pembelajaran interaktif adalah Macromedia Flash 8 dan Adobe Flash[4]. Media pembelajaran berisi tentang informasi pelajaran yang akan di pakai oleh para guru untuk menyampaikan sebuah pelajaran. TK Pertiwi Pacitan dalam hal pembelajaran huruf hijaiyah dengan cara konvensional. Cara tersebut membuat anak menjadi tidak tertarik untuk belajar. Merubah cara konvensional ke media animasi interaktif merupakan usaha media pembelajaran di TK Pertiwi untuk membuat anak lebih tertarik untuk belajar[5].

Usia dini merupakan usia emas bagi anak dalam menerima dan menangkap hal yang baru. Memberikan pengetahuan sejak usia dini dapat mempengaruhi pola pikir anak tersebut dengan memadukan pelajaran dan perkembangan teknologi baik teks, gambar, audio, animasi gambar dapat menambah semangat anak-anak dalam proses belajar[6]. Kurang menariknya belajar mengenal warna, angka, huruf dan bentuk dengan cara biasa membuat rasa ingin tahu anak berkurang. Dengan aplikasi berbasis multimedia dan pendekatan model waterfall bertujuan membantu anak dalam proses pembelajaran mengenal warna, angka, huruf dan bentuk menjadi tidak membosankan[7]. Masuknya budaya dari luar negeri membuat remaja sudah banyak yang melupakan nilai-nilai bangsa sendiri dan mereka seakan telah lupa memiliki dasar negara sendiri yaitu Pancasila. Pengenalan lambang negara Garuda Pancasila pada usia dini amat penting. Dengan menggunakan pembelajaran audio visual berupa animasi interaktif yang di dalamnya menyajikan sebuah interface yang menarik kepada masyarakat khususnya anak-anak sekolah dasar (kelas 4-6) sehingga dapat mengetahui kandungan, nilai-nilai serta sejarah dan ideologi pancasila dari Lambang Garuda Pancasila sejak dini[8].

Melalui multimedia animasi interaktif suasana belajar dirasa lebih menyenangkan anak - anak dalam belajar bahasa Sunda. Penelitian ini bertujuan menghasilkan dan mengetahui persepsi siswa terhadap aplikasi animasi pembelajaran bahasa Sunda. Penelitian ini menggunakan model ADDIE. Kebutuhan dalam mengenal bahasa Sunda mulai dari anggota tubuh, keluarga, benda terdekat, dan quiz sebagai evaluasi pemahaman pembelajaran. Target dari pengguna aplikasi ini ditujukan untuk siswa sekolah dasar. Hasil penghitungan persepsi siswa dengan nilai rataratanya sebesar $82.6 \%$ menunjukan hasil yang sangat baik[9]. Teknologi informasi merupakan salah satu cara untuk mengumpulkan dan menyebarkan surat Sunda untuk memperkenalkan dan melestarikan huruf budaya Sunda. Dengan metode Multimedia Development Life dan tampilan melalui multimedia dalam pengenalan huruf sunda diharapkan menarik untuk mempelajari huruf sunda. Hal ini tidak hanya melalui gambar tetapi juga dengan suara yang membuatnya lebih mudah untuk belajar[10].

Pelajaran bahasa inggris adalah salah satu pelajaran yang dianggap cukup sulit oleh sebagian besar siswa sekolah dasar, termasuk siswa pada Madrasah Ibtidaiyah(MI) Al-Khairiyah Bekasi. 
Penyampaian materi Bahasa Inggris masih menggunakan teknik konservatif yaitu hanya menggunakan sebuah text book atau buku panduan dan guru menjelaskan dengan ceramah serta siswa menyimak buku pelajaran tersebut. Teknik pembelajaran seperti ini menimbulkan kepenatan bagi para peserta didik, hal ini terlihat dari kurangnya semangat mereka saat belajar sehingga proses belajar menjadi kurang efektif serta pencapaian tingkat keberhasilan belajar siswa tidak terpenihi dengan baik penggunaan media edukasi berupa animasi dapat menjadi salah satu cara meningkatkan minat belajar siswa serta sebagai sarana pengenalan teknologi informasi. Siswa dapat memahami cara membaca kalimat bahasa inggris dengan baik dan benar[11]. Mempelajari huruf dan angka dengan bahasa Inggris pada saat ini sangat penting bagi anak-anak. Maka dari itu bagaimana kita menghidupkan metode pembelajaran agar mudah di dapat dengan harga terjangkau dan dapat bisa menarik anak-anak dalam belajar. Mulai dari segi gambar, animasi, suara, game, cara pengejaan yang baik dan benar dapat di kemas semenarik mungkin dan sekarang dapat dilakukan dengan software animasi sehingga anak-anak lebih tertarik dalam belajar bahasa Inggris[12].

Menguasai bahasa Inggris adalah keterampilan yang sangat penting dalam era informasi dan komunikasi saat ini. Hal tersebut sebagai modal untuk dukungan sosial dan karir yang luas, menyadari pentingnya menguasai bahasa yang perlu diajarkan dari pendidikan usia dini tentunya, perlu bimbingan dan rujukan dari guru dan orang tua. Pada saat ini di PAUD Al-Hasanah Cilimbung Tasikmalaya pembelajaran masih menggunakan cara tradisional yaitu dengan menulis dan menggambar bahan di papan tulis dan masih belum lengkap fasilitas pendukung untuk bahan pembelajaran. Tentunya hal ini kurang efektif siswa merasa kurang kurang memahami dan minat pada materi yang diajarkan, untuk mengatasi masalah tersebut maka diperlukan cara baru pembelajaran bahasa Inggris. Cara yang digunakan yaitu dengan menggunakan teknologi media interaktif yang diharapkan dapat mendukung optimalisasi pembelajaran yang menyenangkan sehingga dapat meningkatkan keterampilan berbahasa inggris[13]. Hal yang diajarkan mendesain animasi berbasis bahasa Inggris dilakukan pembelajaran bahasa Inggris menggunakan Adobe Flash CS5 dan Adobe Photoshop CS6. Setelah merancang dan mengimplementasikan model multimedia dalam pembelajaran bahasa inggris berbasis multimedia di PAUD Al-Hasanah Cilimbung Tasikmalaya maka hasilnya ternyata siswa dan guru sangat senang[14]. 
INTENSIF, Vol.3 No.2 August 2019

ISSN: 2580-409X (Print) / 2549-6824 (Online)

DOI: https://doi.org/10.29407/intensif.v3i2.12666

Langkah-langkah dalam model pengembangan perangkat lunak dengan model ADDIE:

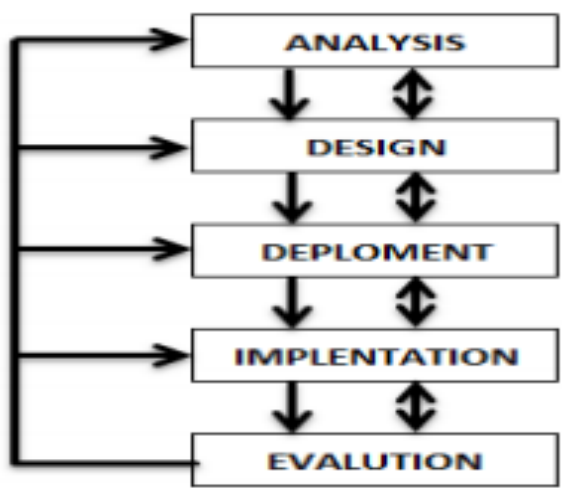

Gambar 1. MODEL PENGEMBANGAN ADDIE[13]

\section{Prosedur ADDIE}

Tahap-tahap model ADDIE:

1. Analysis

Menganalisis kebutuhan dalam aplikasi animasi, pengguna aplikasi, analisis perangkat lunak dan analisis spesifikasi.

2. Design

Mulai dari storyboard, materi dan soal evaluasi, gambar dan tombol pada aplikasi.

3. Pembangunan (Development)

Mulai dari pembuatan animasi interaktif.

4. Penerapan (Implementation)

Merupakan tahap uji coba media dan evaluasi. Kemudian diperoleh produk akhir berupa media pembelajaran berupa aplikasi animasi interaktif pembelajaran huruf dan angka.

\section{Teknik Pengumpulan Data}

Penelitian ini menggunakan sampel data sebanyak 50 siswa. Data dikumpulkan dengan teknik observasi, wawancara dan menggunakan angket penilaian dari siswa.

\section{Teknik Analisis Data}

Data yang sudah terkumpul dari sumber data kemudian dikalkulasikan persentasenya dengan rumus penilaian kelayakan.

$$
R S=\frac{n}{N} X 100 \%
$$

Dengan :

$\mathrm{RS}=$ Persentase sub variabel

$n=$ Jumlah nilai tiap sub variabel

$N=$ Jumlah skor maksimum 
INTENSIF, Vol.3 No.2 August 2019

ISSN: 2580-409X (Print) / 2549-6824 (Online)

DOI: https://doi.org/10.29407/intensif.v3i2.12666

Tabel 1. Range Persentase AngKet Kriteria KualitatiF

\begin{tabular}{cc}
\hline \hline$\underline{\text { Interval }}$ & $\underline{\text { Kriteria }}$ \\
\hline $84,0 \%-100 \%$ & Sangat baik \\
$68,0 \%-83,9 \%$ & Baik \\
$52,0 \%-67,9 \%$ & Cukup baik \\
$36,0 \%-51,9 \%$ & Kurang baik \\
$20,0 \%-35,9 \%$ & Tidak baik \\
\hline
\end{tabular}

Penelitian ini, aplikasi animasi interaktif pembelajaran huruf dan angka yang dikembangkan dikatakan layak apabila hasil skor validasi yang diperoleh $>67 \%$.

\section{HASIL DAN PEMBAHASAN}

\section{A. Analysis}

Materi yang disajikan dalam media pembelajaran yang akan dikembangkan dengan Adobe Flash CS6 untuk pembuatan animasi. Berdasarkan analisa kebutuhannya Animasi interaktif ini dirancang dimulai dari tampilan awal, menu utama mengenal huruf dan angka, kuis dan game.

\section{B. Design}

Susunan Storyboardnya sebagai berikut:

1. Storyboard menu opening

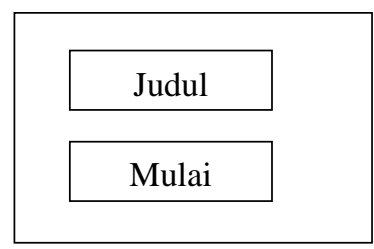

\section{Gambar 2. STORYBOARD TAMPILAN MENU OPENING}

Desain storyboard opening saat aplikasi dibuka, akan ada daun dan seorang anak laki-laki dan perempuan mengajak untuk memulai sebelum itu ia akan membacakan judul animasi selanjutnya ada huruf dan angka kemudian ada tombol mulai untuk memulai aplikasi. Audio yang digunakan adalah musik the basket. Desain tampilan dapat dilihat pada gambar 2.

2. Storyboard tampilan menu utama

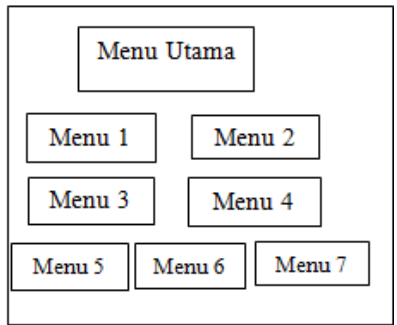

Gambar 3. STORYBOARD MENU UTAMA 
INTENSIF, Vol.3 No.2 August 2019

ISSN: 2580-409X (Print) / 2549-6824 (Online)

DOI: https://doi.org/10.29407/intensif.v3i2.12666

Desain storyboard pada gambar 3 yaitu menu utama saat masuk kedalam manu utama, terdapat beberapa pilihan menu diantaranya:

a. Menu belajar huruf dimana ketika di klik akan muncul tampilan huruf dari A sampai Z disetiap huruf terdapat tampilan gambar dan keterangan ketika diklik bagian hurufnya.

b. Menu belajar angka dimana ketika di klik akan muncul tampilan huruf dari 1 sampai 10 di setiap angka terdapat tampilan gambar sesuai banyaknya angka.

c. Menu latihan saat di klik akan tambil 2 sub menu menghitung dan memasang huruf saat diklik menu permainan akan muncul 3 menu permainan tangkap angka, tangkap huruf, tangkap angka dan huruf.

d. Menu video, didalam menu ini terdapat 3 video lagu anak-anak.

e. Menu Profil, didalamnya terdapat profil pembuatan animasi interaktif.

f. Menu keluar, ketika di klik akan muncul tampilan Terimakasih

3. Storyboard menu belajar huruf dan pengenalan angka
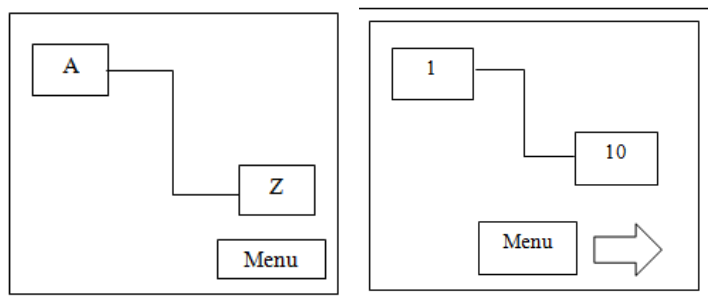

Gambar 4. STORYBOARD MENU BELAJAR HURUf DAN PENGENALAN ANGKA

Desain storyboard gambar 4 terdiri dari dua desain yaitu pada menu belajar huruf didalamnya terdapat huruf A sampai $\mathrm{Z}$ dimana ketika diklik salah huruf akan tampil suara dan contoh dan gambar dan disertai cara pengucapannya. Pada menu belajar angka didalamnya terdapat angka 1 sampai 10 dimana jika diklik salah angka akan tampil suara dan contoh dan gambar dan disertai cara pengucapannya.

4. Storyboard Tampilan materi Huruf
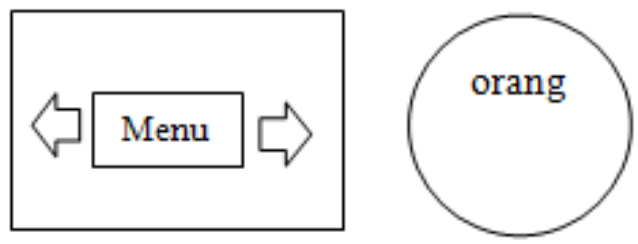

\section{Gambar 5. STORYBOARD TAMPILAN MATERI HURUF DAN MATERI ANGKA}

Desain storyboard tampilan materi terdiri dari dua yaitu pada tampilan materi huruf terdapat 3 tombol diantaranya tombol kembali tombol selanjutnya dan tombol menu. Dimana pada saat di 
klik tombol kembali maka akan kembali ke tampilan materi sebelumnya. Sebaliknya ketika diklik tombol selanjutnya maka akan berlanjut kemateri selanjutnya dan apabila diklik tombol menu maka akan kembali ketampilan menu belajar huruf. Selain itu terdapat pula pengertian dan cara penguapkan. Pada tampilan materi angka terdapat 3 tombol diantaranya tombol kembali tombol selanjutnya dan tombol menu. Dimana pada saat di klik tombol kembali maka akan kembali ke tampilan materi sebelumnya. Sebaliknya ketika diklik tombol selanjutnya maka akan berlanjut kemateri selanjutnya dan apabila diklik tombol menu maka akan kembali ketampilan menu belajar huruf. Selain itu terdapat pula pengertian dan cara penguapkan.

5. Storyboard menu latihan

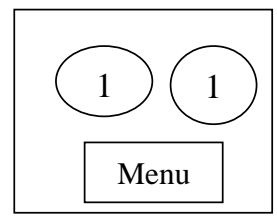

Gambar 6. STORYBOARD MENU LATIHAN

Pada menu latihan sesuai dengan desain pada gambar 6 terdapat 2 pilihan latihan dari tombol menu. Dimana saat salah satu latihan diklik akan tampil pernyataan, juga pada saat diklik tombol maneu maka akan tampil kembali kemenu utama.

6. Storyboard menu latihan menghitung objek

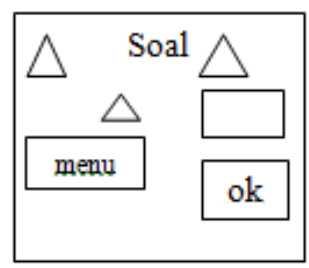

\section{Gambar 7. STORYBOARD MENU LATIHAN MENGHITUNG OBJEK}

Pada tampilan latihan yaitu pada gambar 7, siswa akan dihadapkan dengan 5 soal yang berbeda dimana setiap soal terdapat gambar jawaban. kemudian siswa harus menjawab sesuai jumlah gambar benar yang ada pada setiap soal dan apabila soal pertama dijawab maka akan otomatis berlanjut ke soal berikutnya sehingga soal ke 5 . Kemudian ketika menjawab soal dengan benar akan ditandai dengan anak kecil tertawa sebaliknya apabila menjawab soal dengan salah maka kan ditanda menggis 
INTENSIF, Vol.3 No.2 August 2019

ISSN: 2580-409X (Print) / 2549-6824 (Online)

DOI: https://doi.org/10.29407/intensif.v3i2.12666

7. Storyboard tampilan latihan memasang objek

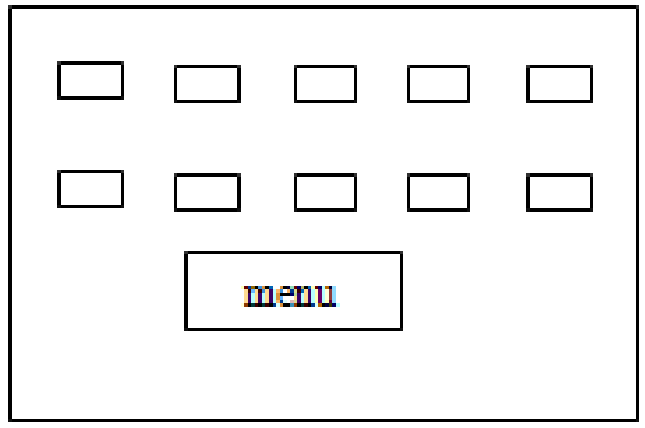

Gambar 8. StoRyboard MENU LATIHAN MEMASANG OBJEK

Pada tampilan latihan yaitu oada gambar 8, siswa akan dihadapkan dengan 5 soal yang berbeda dimana setiap soal terdapat gambar jawaban. kemudian siswa harus menjawab sesuai jumlah gambar benar yang ada pada setiap soal dan apabila soal pertama dijawab maka akan otomatis berlanjut ke soal berikutnya sehingga soal ke 5. Kemudian ketika menjawab soal dengan benar akan ditandai dengan anak kecil tertawa sebaliknya apabila menjawab soal dengan salah maka kan ditandai anak menanggis.

8. Storyboard tampilan Score latihan

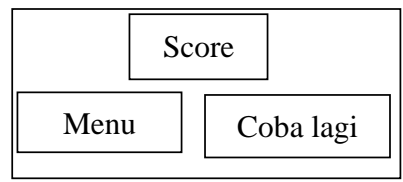

\section{Gambar 9. STORYBOARD MENU SCORE LATIHAN}

Pada tampilan gambar 9 yaitu score kuis terdapat tampilan jumlah nilai dan juga terdapat 2 tombol yakni tombol kembali dan tombol coba lagi.

\section{DEVELOPMENT}

1. Tampilan Menu Opening

Tampilan pertama aplikasi yaitu pada gambar 10 terdapat tombol mulai, judul aplikasi dan 2 anak, laki-laki dan perempuan. Klik tombol mulai untuk masuk ke menu utama.

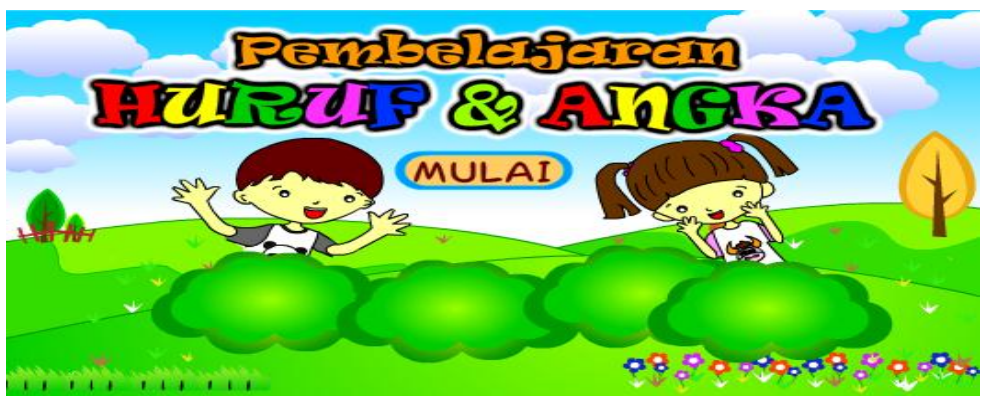

Gambar 10. USER INTERFACE OPENING 


\section{Tampilan Menu Utama}

Pada menu utama pada gambar 11 terdapat tampilan tombol belajar huruf, angka, latihan menghitung dan memasang huruf, permainan, video, profil dan keluar.

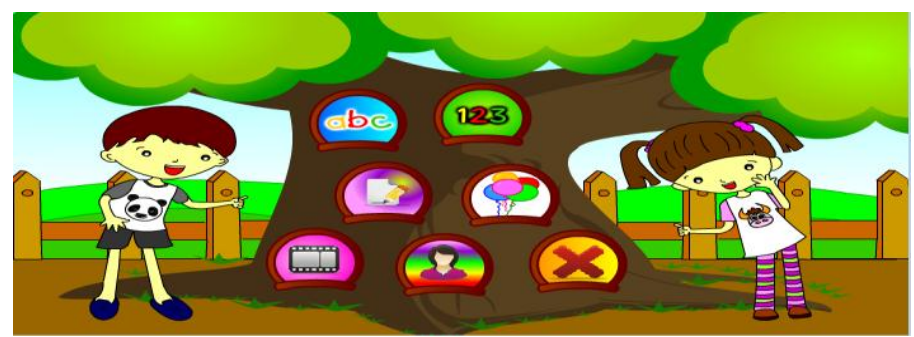

Gambar 11. USER INTERFACE UTAMA

3. Tampilan Menu belajar huruf

Dimenu ini terdapat tampilan gambar 12 huruf Aa sampai Zz jika diklik huruf tersebut akan muncul suara dan contoh gambar 13 penggunaan huruf tersebut serta cara pengucapannya.

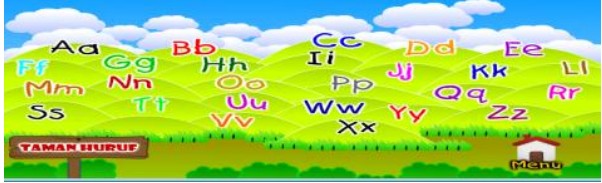

Gambar 12. USER INTERFACE BELAJAR HURUF

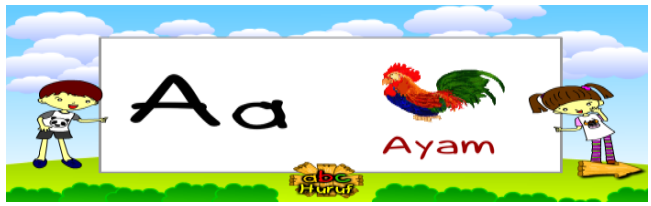

Gambar 13. USER INTERFACE MATERI

4. Tampilkan Menu Materi Angka

Menu pada gambar 14 menampilkan angka 1 - 10, jika tampilan gambar 15 diklik akan muncul suara, gambar dan cara pengucapannya.

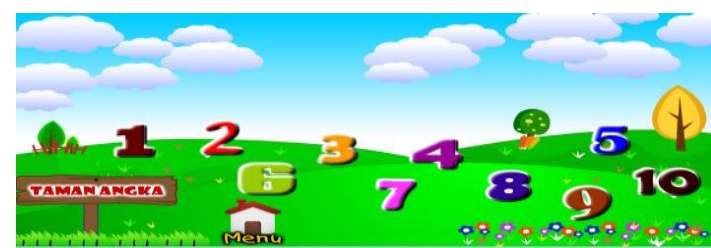

Gambar 14. USER INTERFACE BELAJAR ANGKA

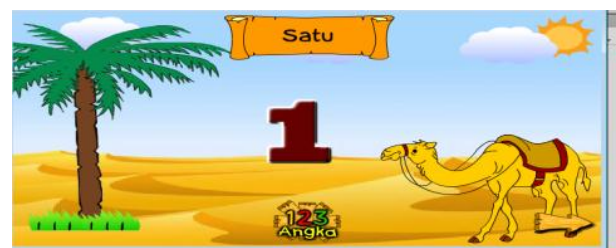

Gambar 15. USER INTERFACE MATERI

5. Tampilan Menu Latihan

Menu pada gambar 16 terdapat 2 tombol menu pilihan yaitu menghitung objek dan memasangkan huruf. Klik menu akan kembali ke menu utama.

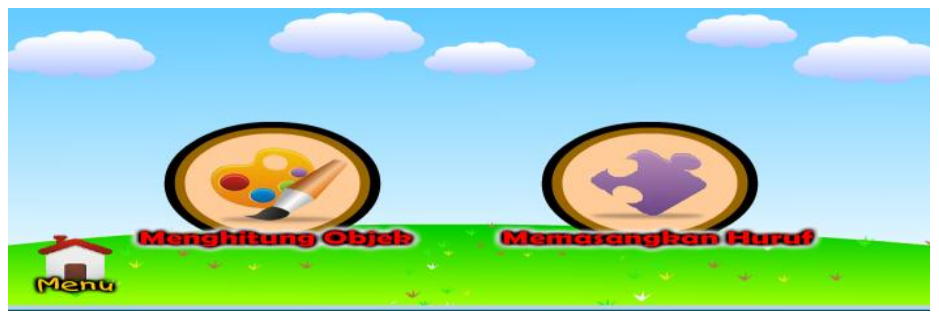

Gambar 16. USER INTERFACE MENU LATIHAN 
INTENSIF, Vol.3 No.2 August 2019

ISSN: 2580-409X (Print) / 2549-6824 (Online)

DOI: https://doi.org/10.29407/intensif.v3i2.12666

6. Tampilan latihan Menghitung

Pada gambar 17 siswa harus menjawab sesuai dengan jumlah gambar yang ada. Jika sudah dijawab maka akan otomatis ke soal berikutnya. Kalau jawaban benar akan ditandai dengan suara anak kecil tertawa, jika salah suara anak kecil menangis.

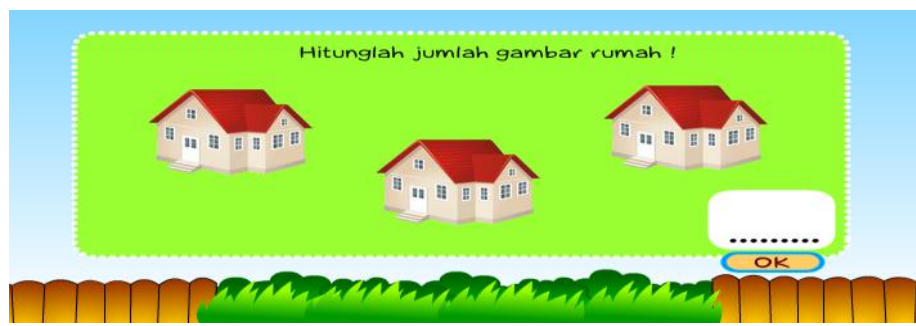

Gambar 17. USER INTERFACE LATIHAN MENGHITUNG

7. Tampilan Menu Bermain

Pada gambar 18 terdapat 3 tombol pilihan games diantaranya games menangkap angka sebanyak mungkin dengan waktu yang telah ditentukan dan games mencari huruf dan angka dan huruf. Klik tombol kembali kemenu utama

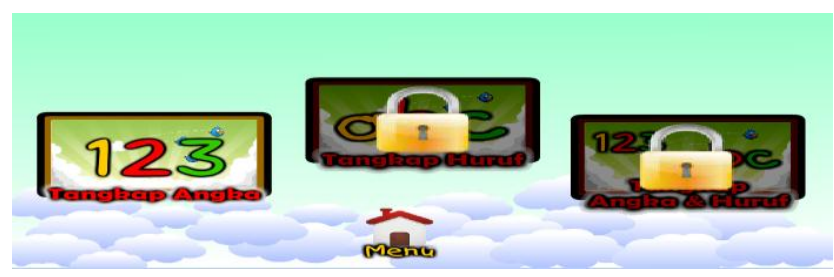

Gambar 18. USER INTERFACE MENU BERMAIN

\section{Tampilan Bermain Tangkap Objek}

Tampilan gambar 19 adalah bermain tangkap objek, terdapat gambar huruf dan gambargambar dimana user akan mengumpulkan huruf yang jatuh dengan waktu yang di tentukan.

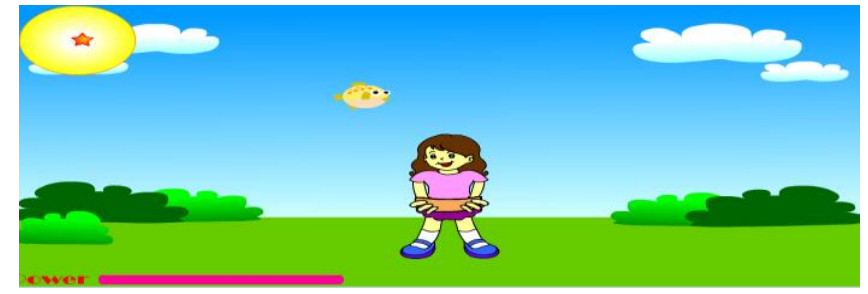

Gambar 19. USER INTERFACE BERMAIN TANGKAP OBJEK

9. Tampilan Score tangkap objek berhasil

Tampilan gambar 20 score menang atau gagal terdapat tombol kembali untuk ke menu bermain dan level untuk ke permainan berikutnya. Pada gambar 21 menunjukkan hasil dari gambar 19. 

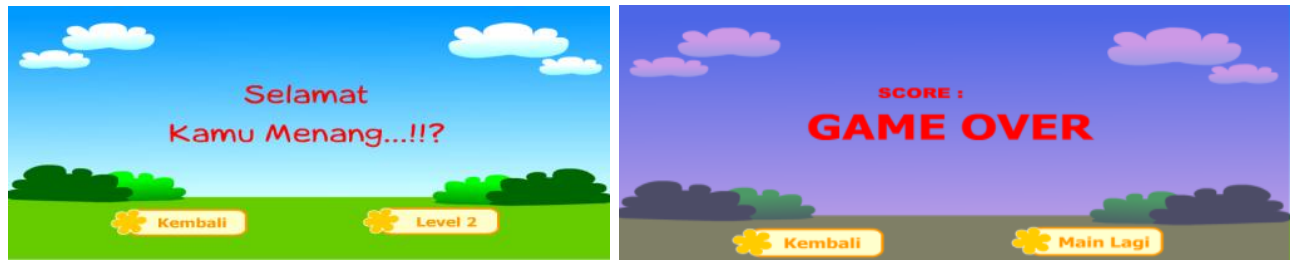

Gambar 20. USER INTERFACE SCORE TANGKAP OBJEK BERHASIL DAN OBJEK GAGAL

10. Tampilan Menu Video

Tampilan gambar 21 terdapat 3 tombol video lagu, jika diklik akan tampil video lagu tersebut.

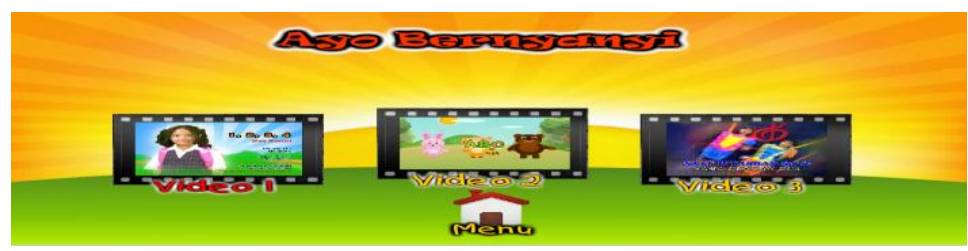

Gambar 21. USER INTERFACE MENU VIDEO

\section{IMPLEMENTATION}

Implementasi sesuai pada tabel 2 yaitu meliputi penerapan spesifikasi perangkat keras, perangkat lunak, pengujian.

Tabel 2. SPESIFIKASI

\begin{tabular}{lr}
\hline \hline Spesifikasi Perangkat Keras & Spesifikasi Perangkat lunak \\
\hline 1. Processor : core i3 $2,0 \mathrm{GHz}$ & 1. System operasi windows 7 \\
2. Memory : $2 \mathrm{~GB}$ & 2. Adobe Flash CS6 Professional \\
3. Harddisk : $80 \mathrm{~GB}$ & 3. Adobe Photoshop CS6 \\
4. Monitor : 14 " LCD & 4. Xilisoft Video Converter \\
& 5. Audacity \\
\hline
\end{tabular}

\section{Pengujian White Box}

Menguji perangkat lunak dari segi desain dan kode program apakah mampu menghasilkan fungsi-fungsi, masukan dan keluaran yang sesuai dengan spesifikasi kebutuhan. Ketika aplikasi dijalankan, maka terlihat bahwa salah satu basis set yang dihasilkan adalah 1-2-3-4-5-6-7-9-dan berdasarkan pengamatan ketentuan tersebut dari segi kelayakan software, sistem ini telah memenuhi syarat. Adapun level 3 alur jalan permainan sama dengan level 2, hanya berupa pada perubahan waktu, jadi dapat dikatakan bahwa hasil pengujian level 3 juga telah memenuhi syarat.

\section{Pengujian Black Box}

Menguji perangkat lunak dari segi spesifikasi fungsional tanpa menguji desain dan kode program. Pengujian proses jalannya aplikasi baik event, input dan output yang dihasilkan harus sesuai dengan rancangan yang telah ditentukan. Hasil pengujian dapat dilihat pada tabel 3. 
INTENSIF, Vol.3 No.2 August 2019

ISSN: 2580-409X (Print) / 2549-6824 (Online)

DOI: https://doi.org/10.29407/intensif.v3i2.12666

Tabel 3. Pengujian Black Box Menu Belajar Huruf

\begin{tabular}{|c|c|c|c|}
\hline INPUT/EVENT & $\overline{\text { PROSES }}$ & $\begin{array}{c}\text { OUTPUT/NEXT } \\
\text { STAGE }\end{array}$ & $\begin{array}{c}\text { HASIL } \\
\text { PENGUJIAN }\end{array}$ \\
\hline Tombol Menu & $\begin{array}{l}\text { on (release) }\{ \\
\text { stopAllSounds(); } \\
\text { gotoAndStop(3);\} }\end{array}$ & $\begin{array}{l}\text { Kembali kemenu } \\
\text { utama }\end{array}$ & Sesuai \\
\hline $\begin{array}{c}\text { Tombol menu huruf } \\
\text { A }\end{array}$ & $\begin{array}{l}\text { on (release) }\{ \\
\text { stopAllSounds(); } \\
\text { gotoAndStop(5);\} }\end{array}$ & $\begin{array}{l}\text { Menampilkan } \\
\text { huruf dan contoh } \\
\text { gambar }\end{array}$ & Sesuai \\
\hline $\begin{array}{c}\text { Tombol menu huruf } \\
\mathrm{Z}\end{array}$ & $\begin{array}{l}\text { on (release) }\{ \\
\text { stopAllSounds(); } \\
\text { gotoAndStop(30); }\end{array}$ & $\begin{array}{l}\text { Menampilan huruf } \\
\text { dan contoh gambar }\end{array}$ & Sesuai \\
\hline
\end{tabular}

\section{E. EVALUATION}

Berdasarkan angket persepsi siswa, didapatkan persentase setiap indikator angket. Persentase indikator aplikasi Belajar Huruf dan Angka dapat dilihat dalam tabel berikut:

TABEL 4. PERSENTASE PERSEPSI SISWA TERHADAP MEDIA PEMBELAJARAN

\begin{tabular}{cccc}
\hline \hline No. & Aspek (kriteria) & $(\%)$ & Kategori \\
\hline 1 & Materi & $82.4 \%$ & Baik \\
\hline 2 & Tampilan media & $84.6 \%$ & Sangat baik \\
\hline 3 & Kualitas media & $80.7 \%$ & Baik \\
\hline & Rata-rata & $82.6 \%$ & Baik \\
\hline
\end{tabular}

Berdasarkan uji coba yang dilakukan kepada siswa TK Ps. Minggu Jakarta Selatan dengan nilai skor validasi $82,6 \%$ secara keseluruhan dapat disimpulkan bahwa aplikasi animasi interaktif pembelajaran yang telah dikembangkan sudah layak digunakan sebagai penunjang pembelajaran untuk siswa dalam materi pengenalan huruf dan angka.

\section{KESIMPULAN DAN SARAN}

Perancangan aplikasi animasi interaktif yang dibangun dengan model ADDIE lebih mudah diterapkan sesuai dengan hasil pengujian dengan skor 82,6\%. Hasil Pengujian dimulai dari analisa, design, implementasi, evaluasi dilakukan secara berurutan. Konsepnya dapat dikembangkan dengan baik sehingga aplikasi yang dihasilkan menjadi lebih baik. Penerapan aplikasi animasi interaktif ini layak digunakan dalam pembelajaran mengenal huruf dan angka untuk siswa. 


\section{DAFTAR PUSTAKA}

[1] T. M. Sri Ariyati, "Perancangan animasi interaktif pembelajaran asmaul husna," J. Tek. Komput. AMIK BSI, vol. II, no. 1, pp. 116-121, 2016. http://ejournal.bsi.ac.id/ejurnal/index.php/jtk/article/viewFile/369/278

[2] J. Karaman, A. Setyanto, and A. F. Sofyan, "Analisis Aplikasi Marbel Huruf Versi Mobile Terhadap Pembelajaran Membaca di Desa Semanding Ponorogo," INTENSIF, vol. 2, no. 2, p. 98, May 2018. doi:10.29407/intensif.v2i2.11878

[3] S. Andriyanto, M. Suyanto, and S. Sukoco, "Implementasi Metode Reynolds menggunakan Simulasi Kerumunan Bebek,” INTENSIF, vol. 1, no. 2, p. 75, Aug. 2017. doi:10.29407/intensif.v1i2.788

[4] H. D. Andaru Mahardika, "ANIMASI INTERAKTIF PEMBELAJARAN PENGENALAN HEWAN DAN ALAT TRANSPORTASI UNTUK SISWA TAMAN KANAK - KANAK," Pilar Nusa Mandiri, vol. 10, no. 1, pp. 100-110, 2014. http://pilar.nusamandiri.ac.id/index.php/pilar/article/view/73/69

[5] C. Budi Susila and E. I. Ganis, "Media Pembelajaran Interaktif Pengenalan Huruf Hijaiyah Pada Taman Kanak-Kanak ( Tk ),” Seruni FTI UNSA, vol. 1, pp. 1-5, 2012. http://portal.ejurnal.net/index.php/seruni/article/view/1033

[6] A. Christian, F. Ariani, and K. Rizal, "Animasi Interaktif Peningkatan Kemampuan Mengenal Huruf Untuk Anak Usia Dini," Simp. Nas. Ilmu Pengetah. dan Teknol., pp. 179-183, 2014. http://seminar.bsi.ac.id/simnasiptek/index.php/simnasiptek2014/article/view/26/26

[7] E. Purwaningsih, "Mengenal Warna, Angka, Huruf Dan Bentuk Pada Anak Usia Dini Melalui Animasi Interaktif," J. Ilmu Pengetah. dan Teknol. Komput., vol. Vol.3 No.2, no. Februari, pp. 203-210, 2018.

http://ejournal.nusamandiri.ac.id/ejurnal/index.php/jitk/article/view/611/405

[8] H. Darmawan and V. Sofica, "Animasi Interaktif Pengenalan Lambang Negara Indonesia Garuda Pancasila," vol. 1, no. 2, pp. 135-144, 2017. http://www.ejournalbinainsani.ac.id/index.php/IMBI/article/view/406/409

[9] S. A. F. E. S. Althafani, "PERANCANGAN ANIMASI INTERAKTIF PENGENALAN BAHASA SUNDA UNTUK ANAK - ANAK METODE ADDIE," J. ILMU Pengetah. DAN Teknol. Komput., vol. 3, no. 2, pp. 195-202, 2018. http://ejournal.nusamandiri.ac.id/ejurnal/index.php/jitk/article/view/644/404

[10] Jenie Sundari, "Melestarikan Aksara Sunda Dengan Aplikasi Multimedia," J. Evolusi, vol. 4, no. 2, pp. 28-32, 2016. 
INTENSIF, Vol.3 No.2 August 2019

ISSN: 2580-409X (Print) / 2549-6824 (Online)

DOI: https://doi.org/10.29407/intensif.v3i2.12666

http://ejournal.bsi.ac.id/ejurnal/index.php/evolusi/article/view/698/573

[11] S. Nurajizah, "Media Edukasi Interaktif sebagai Sarana Pembelajaran Bahasa Inggris untuk Siswa Sekolah Dasar pada MI Al-Khairiyah Bekasi,” vol. III, no. 2, pp. 83-89, 2017. http://ejournal.bsi.ac.id/ejurnal/index.php/jtk/article/view/1961/1515

[12] Kusnadi dkk, "Pembelajaran Bahasa Inggris Berbasis Multimedia ( Studi Kasus : Paud Al-Hasanah Cilimbung Tasikmalaya )," vol. 4, no. 1, pp. 1-7, 2018. http://ejournal.bsi.ac.id/ejurnal/index.php/jtk/article/view/2401/1898

[13] D. Setiawan, I. Arifin, and R. Ardianto, "Implementasi Pengembangan Sistem Media Pembelajaran Pengenalan Komputer," INTENSIF, vol. 2, no. 2, p. 127, May 2018.

[14] M. Molenda, "In Search of the Elusive ADDIE Model. Indiana University," [Online]., 2003. 